www.jmscr.igmpublication.org

Impact Factor 3.79

ISSN (e)-2347-176x ISSN (p) 2455-0450

crossref DOI: _http://dx.doi.org/10.18535/jmscr/v3i11.03

Journal Of Medical Science And Clinical Research

IGM Publication

An official Publication of IGM Publication

\title{
Study of Insulin-Like Growth Factor-1 and Insulin-Like Growth Factor Binding Protein-1 Relation to Insulin Resistance in Normal Persons and Type 2 Diabetics
}

\author{
Authors \\ Khalifa A.M. ${ }^{1}$, Ismael A.A.,El Neily D.A. ${ }^{2}$, Abd El Ghafour R.A. ${ }^{1}$ \\ ${ }^{1}$ Internal Medicine Department, Faculty of Medicine, University of Alexandria, Egypt \\ ${ }^{2}$ Clinical Pathology Department, Faculty of Medicine, University of Alexandria, Egypt \\ Corresponding author \\ Reem Ahmed Mohammed Abd El Ghafour (Abd El Ghafour R.A.) \\ Specialist of Internal Medicine, Damanhour Medical Institute, Egypt \\ Email:reemdoc10@yahoo.com,phone:00201227943121
}

\begin{abstract}
Aim and Background: IGF binding proteins predominantly control the access of IGFs to tissues and cellsurface IGF receptors. Of these, IGFBP-1 is the most likely candidate for acute regulation of IGF actions because of its acute down regulation by insulin and upregulation by other glucoregulatory hormones and cytokines and in catabolic states. This study was undertaken to to assess the relation of the IGF-1 and IGFBP-1 to insulin resistance in a group of adult Egyptian diabetics and non diabetic population.

Subjects and Methods: This study was conducted on 45 adult males with age between 20-50 years. They were divided into group I $(n=25)$ type 2 diabetics and group II $(n=20)$ non diabetics. Patient s general information was noted, anthropometrical measurements were conducted and The eligible participants were asked to overnight fast for 8 hours. Blood was sampled for FBG, fasting Insulin, fasting IGF1, fasting IGFBP-1 And IR (HOMA-IR) was analyzed. Insulin and IGF-1 were analyzed by chemiluminescent immunoassay, FBG was analyzed by the glucose oxidase (enzymatic oxidation) method and IGFBP-1 was analyzed by IGFBP-1 ElLISA

Results: Diabetic group had IGFI $(P=0.0001)$ and IGFBP-1 $(P=0.041)$ values statistically lower than non diabetic group. Diabetic group had a significant negative correlation between levels of FBG and those of IGF$1(p=0001)$. We noted that, diabetic group had a significant negative correlation between IGF-1 and IR(HOMA$I R)(p=.045)$ and a significant negative correlation between IGFBPI and IR(HOMA-IR) $(p=.046)$.

Conclusion: IGF1 and IGFBP-1 seems to be at lower levels in Type 2diabetics than in normal subjects, IGF1 seems to be negatively associated with fasting glucose in Type 2diabetics and Insulin resistance (HOMA-IR) seems to be negatively associated with IGFI and IGFBP-1 in Type 2diabetics.

Keywords: IGFBP-1,IGF-1, IR(HOMA-IR), Type 2diabetics
\end{abstract}

\section{Introduction}

This review addresses the possible role of the insulin-like growth factor (IGF)- axis in normal glucose homoeostasis and in the etiopathogenesis of type 2 diabetes. The three peptide hormones or growth factors, in the IGF family-insulin, IGF-I, and IGF-II-have approximately 50 percent of their amino acids in common. Insulin is synthesized in the beta cells of the pancreas as proinsulin, which is cleaved to form insulin and $\mathrm{C}$ peptide. The 
IGFs, which are synthesized primarily by the liver, retain the $\mathrm{C}$ peptide and have an extended carboxy terminus. ${ }^{(1)}$

In several pathological states, an impairment of IGF-1 action on glucose metabolism has been recorded, along with insulin resistance; (2) however, it is not known whether IGF-1 and insulin resistance are always associated and it is not clear whether resistance, when it does occur, affects only glucose uptake and metabolism or protein metabolism as well.

IGF-I, a peptide hormone, shares amino acid sequence homology with insulin and has insulinlike activity; most notably, the promotion of glucose uptake by peripheral tissues. Although IGF-1 is structurally related to insulin, unlike insulin, it circulates bound to specific proteins called IGF binding proteins (IGFBPs) with variable affinity ${ }^{(3)}$ Insulin-like growth factor binding proteins (IGFBPs) that are present in extracellular fluids have been shown to modulate the biological activity of IGFs. ${ }^{(4)}$ Both stimulatory and inhibitory effects of IGFBPs on IGF actions have been described and IGF-independent effects of several IGFBPs are emerging.

Accumulating evidence indicates important roles for members of the IGFBP family in metabolic homeostasis. For example, IGFBP-1 concentrations fluctuate inversely in response to changes in plasma insulin levels, implicating IGFBP-1 in glucoregulation, and fasting levels of IGFBP-1 predict insulin sensitivity. IGFBP-1 has been proposed as the binding protein most likely to modulate the acute metabolic effects of IGFs, ${ }^{(5)}$ because uniquely among the IGFBPs, it is acutely regulated by glucoregulatory hormones-insulin (inhibition) and cortisol and glucagon (stimulation). ${ }^{(6)}$ Circulating IGFBP-1 derives from the liver, where inhibition of synthesis by changing hepatic portal insulin concentrations provides a connection between insulin levels and the hypoglycemic potential of IGF-I. ${ }^{(7)}$ Insulin inhibits the hepatic synthesis and secretion of IGFBP- $1^{(8)}$ and increases the portal concentrations of insulin decrease serum levels of IGFBP-1 in obese subjects. ${ }^{(9)}$

Conditions characterized by insulin resistance (including obesity, metabolic syndrome, type 2 diabetes and polycystic ovarian syndrome) are associated with decreased IGFBP-1 levels. (10) IGFBP-1 concentrations correlate with insulin sensitivity in pubertal children, ${ }^{(11)}$ healthy young volunteers ${ }^{(12)}$, elderly adults ${ }^{(13)}$ and patients with glucose intolerance or type 2 diabetes. ${ }^{(14)}$

In a prospective case-control study of Swedish men, low fasting IGFBP-1 concentrations predicted the development of diabetes over ten years, ${ }^{(15)}$ when low IGFBP-1 concentrations were combined in an algorithm with glucose levels, waist measurements, height measurements and proinsulin levels, individuals in the highest quartile were found to have a 40 -fold increased risk of developing diabetes. Although this study shows convincingly that, low IGFBP-1 levels predict development of diabetes, IGFBP-1 levels actually increased by almost a third in individuals who developed diabetes within the next ten years. ${ }^{(15)} \mathrm{A}$ potential explanation might be that low IGFBP-1 levels enable the development of diabetes, but as diabetes develops, IGFBP-1 concentrations rise as a consequence of hepatic insulin resistance or increased cytokine levels. The effects of emerging insulin resistance on IGFBP-1 concentrations require confirmation in other studies.

\section{Aim and objectives}

The aim of the present study was to assess the relation of the insulin-like growth factor-1 and Insulin-like growth factor binding protein-1 to insulin resistance in a group of adult Egyptian diabetics and non diabetic population.

\section{Subjects and Methods}

This study comprised 45 adult males, with age ranging from 20 to 50 years. Participants were selected at random from outpatient clinics in Alexandria Main University Hospital. A group of 25 diabetic subjects were selected from the Out- 
Patient Department, along with a group of 20 healthy subjects as Controls considering the same socio-economic status. A group of patients with type 2 diabetes was matched with a control group with normal fasting glucose levels. Both groups were of comparable BMI.

The purpose of this study and the methods of investigation were explained to participants At first, the response of the people was not enthusiastic as they asked about the purpose of the study, But, explaining the purpose of the study has encourage them to participate. Written consent was taken from all the volunteers; clinical examinations were undertaken using a predesigned questionnaire. Patients with hepatic, renal, neurological, endocrinological or other systemic disease were excluded from this work by history, examination and routine laboratory investigations. The people of this study had no special life style, no special foods.

Subjects were requested to come on a prescheduled morning, after overnight fasting for 8 hours (no caloric intake for 8 hours). No special diet or restriction was recommended the day before the investigations.

\subsection{Demographic and Clinical assessment}

All study subjects were subjected to history taking including age, duration of diabetes and complete physical examination including anthropometric measurements. Height and body weight were measured using a digital scale, and body mass index (BMI) was calculated as follows: $\mathrm{BMI}=$ body weight $(\mathrm{kg}) /$ height squared $\left(\mathrm{m}^{2}\right)$. A body mass index $<25 \mathrm{~kg} / \mathrm{m} 2$ was considered to be normal. Systolic and diastolic blood pressures were measured in a sitting position after a 5-min rest. Patients were categorized as hypertensive patients if the systolic blood pressure was $>140$ $\mathrm{mm} \mathrm{Hg}$ and / or diastolic blood pressure was $>90$ $\mathrm{mm} \mathrm{Hg}$.

\subsection{Laboratory investigations}

Taking an aseptic precaution, $3 \mathrm{ml}$ of venous blood was taken. We estimated plasma glucose by the glucose oxidase (enzymatic oxidation) method, fasting serum Insulin was analyzed by chemiluminescent immunoassay and Insulin growth factor-1 was analyzed by chemiluminescent immunoassay. Insulin growth factor binding protein-1 was analyzed by IGFBP-1 EILISA and Insulin resistance was measured by HOMA-IR.

All blood samples were obtained after an overnight fast, and the patients' usual medications were withheld until after venesection. Plasma was separated from the remaining blood by centrifugation at $4^{\circ} \mathrm{C}$. Plasma samples were stored at $\_70^{\circ} \mathrm{C}$ until analysis.

\subsection{Statistical analysis}

Data were expressed as mean \pm SD (standard deviation), median (range) and/or percentage (\%) as appropriate using SPSS (Statistical Package for Social Science) software. The statistical significance of the differences between the values was assessed by Student's' $t$ ' test. A two-tailed $p$ value of $<0.05$ was considered to be statistically significant.

\section{Results}

\subsection{Clinical characteristics of the study subjects}

There were no statistical significant differences between the two studied groups regarding age, BMI, Systolic blood pressure and Diastolic blood pressure. Type 2 diabetic group have FBG values $(\mathrm{P}=0.001)$ statistically higher than non diabetic group. (Table1)

\subsection{Serum IGF-1, IGFBP-1, Insulin and IR (HOMA-IR) status of the study subjects.}

Type2 diabetic group have IGF1 values statistically lower than control group ( $\mathrm{P}=0.0001)$. Control group have IGFBP1 values statistically higher than Type2 diabetic group $(\mathrm{P}=0.041)$. Type2 diabetic group have Insulin values statistically higher than control group $(\mathrm{P}=0.001)$. We noted also that, Type 2 diabetic group have IR (HOMA-IR) values statistically higher than control group ( $\mathrm{P}=0.0001)$. (Table 2) 


\subsection{Correlation between different studied} parameters among diabetics.

There was negative significant correlations between FBS and IGF1( $\mathrm{r}=-.517, \mathrm{p}=.0001)$, IGF1 and IR (HOMA-IR) (r=-.300, p=.045) and also, a negative significant correlation was found between IGFBP1 and IR(HOMA-IR) ( $\mathrm{r}=-.315$, $\mathrm{p}=.046)$. There was a positive significant correlation between FBS and IR(HOMA-IR) $(\mathrm{r}=.496, \mathrm{p}=.001)$, insulin level and IR(HOMA-IR) $(\mathrm{r}=.719, \mathrm{p}=.0001)$. Other variables showed no significant correlations. (Table 3 )
4.4 Correlation between different studied parameters in control group.

No significant correlation between all studied variables in control group except the positive correlation( $\mathrm{r}=.797, \mathrm{p}=.0001)$ between IR (HOMAIR) and insulin level. (Table4)

Table (1): Clinical characteristics of the study subjects

\begin{tabular}{|l|l|l|l|}
\hline Variable & Control & Diabetics & Sig. \\
\hline Age & $43.8000 \pm 9.32794$ & $45.7600 \pm 4.93525$ & .370 \\
\hline BMI & $29.3505 \pm 5.28115$ & $30.3888 \pm 5.03672$ & .505 \\
\hline FBG & $82.6000 \pm 7.55611$ & $143.9200 \pm 57.49994$ & .0001 \\
\hline Systolic blood pressure & $79.0000 \pm 6.40723$ & $81.4000 \pm 13.74773$ & .858 \\
\hline Diastolic blood pressure & $118.5000 \pm 27.39093$ & $125.6000 \pm 11.21011$ & .244 \\
\hline
\end{tabular}

Results are expressed as $\mathrm{M} \pm \mathrm{SD} . \mathrm{p}<0.05$, significantly different compared to controls when using Student's ' $t$ ' Test

Table (2): Serum IGF-1, IGFBP-1, Insulin and IR (HOMA-IR) status of the study subjects

\begin{tabular}{|l|l|l|l|}
\hline Variable & Control & Diabetics & Sig. \\
\hline IGF1 (ng/ml) & $164.3500 \pm 72.21696$ & $76.7600 \pm 69.00057$ & .0001 \\
\hline IGFBP1(pg/ml) & $1742.5000 \pm 649.88157$ & $1301.2000 \pm 731.93989$ & .041 \\
\hline Insulin $(\boldsymbol{\mu I U} / \mathbf{m L})$ & $7.2475 \pm 8.72594$ & $32.9540 \pm 30.69926$ & .001 \\
\hline IR(HOMA-IR) & $.7300 \pm .90269$ & $4.4760 \pm 3.83148$ & .0001 \\
\hline
\end{tabular}

IGF-1 = insulin like growth factor-1, IGFBP-1 = insulin like growth factor binding protein-1 and HOMAIR=homeostasis model assessment of insulin resistance.

$\mathrm{p}<0.05$, significantly different compared to controls when using Student's 't' test 
Table (3): Correlation between different studied parameters among diabetics

\begin{tabular}{|c|c|c|c|c|c|c|c|}
\hline & & FBS mg/dl & $\begin{array}{c}\text { IGF1 } \\
\mathrm{ng} / \mathrm{ml}\end{array}$ & $\begin{array}{r}\text { IGFBP-1 } \\
\mathrm{pg} / \mathrm{ml}\end{array}$ & Insulin & IR & BMI \\
\hline IGF1 ng/ml & $\begin{array}{l}\mathrm{r} \\
\mathrm{p}\end{array}$ & $\begin{array}{r}-.517^{* * *} \\
.0001\end{array}$ & & & & & \\
\hline IGFBP-1 pg/ml & $\begin{array}{l}\mathrm{r} \\
\mathrm{p}\end{array}$ & $\begin{array}{r}-.278 \\
.064\end{array}$ & $\begin{array}{r}.16 \\
.233\end{array}$ & & & & \\
\hline Insulin & $\begin{array}{l}\mathrm{r} \\
\mathrm{p}\end{array}$ & $\begin{array}{l}.264 \\
.080 \\
\end{array}$ & $\begin{array}{r}-.175 \\
.250 \\
\end{array}$ & $\begin{array}{r}-.155 \\
.310\end{array}$ & & & \\
\hline IR & $\begin{array}{l}\mathrm{r} \\
\mathrm{p}\end{array}$ & $\begin{array}{r}.496^{* * *} \\
.001\end{array}$ & $\begin{array}{r}-.300^{*} \\
.045\end{array}$ & $\begin{array}{r}-.315^{*} \\
.046\end{array}$ & $\begin{array}{l}.719^{* * *} \\
.0001\end{array}$ & & \\
\hline BMI & $\begin{array}{l}\mathrm{r} \\
\mathrm{p}\end{array}$ & $\begin{array}{l}.003 \\
.986\end{array}$ & $\begin{array}{r}-.220 \\
.147\end{array}$ & $\begin{array}{l}.038 \\
.803\end{array}$ & $\begin{array}{l}.083 \\
.586\end{array}$ & $\begin{array}{l}.018 \\
.905\end{array}$ & \\
\hline Duration of DM & $\begin{array}{l}\mathrm{r} \\
\mathrm{p}\end{array}$ & $\begin{array}{l}.232 \\
.264\end{array}$ & $\begin{array}{r}-.013 \\
.952\end{array}$ & $\begin{array}{l}.098 \\
.642\end{array}$ & $\begin{array}{r}-.071 \\
.736\end{array}$ & $\begin{array}{l}.053 \\
.803\end{array}$ & $\begin{array}{r}-.432^{*} \\
.031\end{array}$ \\
\hline
\end{tabular}

**. Correlation is significant at the 0.01 level (2-tailed).

*. Correlation is significant at the 0.05 level (2-tailed).

Table (4): Correlation between different studied parameters in control group

\begin{tabular}{|c|c|c|c|c|c|}
\hline & $\begin{array}{r}\text { FBS } \\
\mathrm{mg} / \mathrm{dl}\end{array}$ & $\begin{array}{l}\text { IGF1 } \\
\text { ng/ml }\end{array}$ & $\begin{array}{r}\text { IGFBP-1 } \\
\mathrm{pg} / \mathrm{ml}\end{array}$ & $\begin{array}{r}\text { Insuli } \\
n\end{array}$ & IR \\
\hline 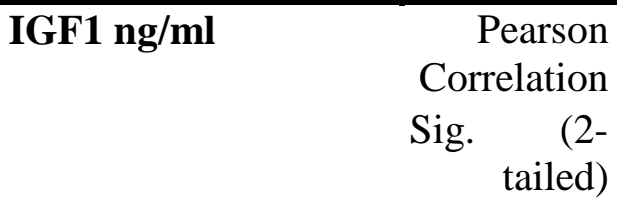 & $\begin{array}{l}.027 \\
.910\end{array}$ & & & & \\
\hline $\begin{array}{lr}\text { GFBP-1 pg/ml } & \text { Pearson } \\
& \text { Correlation } \\
& \text { Sig. } \begin{array}{r}(2- \\
\text { tailed })\end{array}\end{array}$ & $\begin{array}{l}.161 \\
.496\end{array}$ & $\begin{array}{l}.257 \\
.274\end{array}$ & & & \\
\hline $\begin{array}{rr}\text { Insulin } & \text { Pearson } \\
& \text { Correlation } \\
\text { Sig. } & (2- \\
& \text { tailed })\end{array}$ & $\begin{array}{l}.062 \\
.796\end{array}$ & $\begin{array}{l}.205 \\
.386\end{array}$ & $\begin{array}{r}-.324 \\
.154\end{array}$ & & \\
\hline $\begin{array}{cr}\text { IR } & \text { Pearson } \\
& \text { Correlation } \\
\text { Sig. } & (2- \\
& \text { tailed })\end{array}$ & $\begin{array}{l}.056 \\
.815\end{array}$ & $\begin{array}{l}.052 \\
.826\end{array}$ & $\begin{array}{r}-.163 \\
.441\end{array}$ & $\begin{array}{l}.797^{* * *} \\
.0001\end{array}$ & \\
\hline $\begin{array}{cr}\text { BMI } & \text { Pearson } \\
\text { Correlation } \\
\text { Sig. } \quad(2- \\
& \text { tailed })\end{array}$ & $\begin{array}{l}.093 \\
.524\end{array}$ & $\begin{array}{l}.186 \\
.427\end{array}$ & $\begin{array}{r}-.161 \\
.497\end{array}$ & $\begin{array}{l}.029 \\
.904\end{array}$ & $\begin{array}{l}.132 \\
.541\end{array}$ \\
\hline
\end{tabular}




\section{Discussion}

Insulin-like growth factors (IGFs) participate in the growth and function of almost every organ in the body. Because of the wide range of their biologic effects and their therapeutic potential in a variety of clinical disorders, the IGFs have become the focus of research by an increasing number of investigators. IGF-I leads to an increase in peripheral glucose uptake and a decreased production of hepatic glucose causing better insulin sensitivity. ${ }^{(16)}$ In a large trial, ${ }^{(17)}$ patients with type-2 diabetes who had IGF-I monotherapy had significantly lower haemoglobin A1C than those on placebo. Similarly, administration of IGF-I to patients with type-1 diabetes is associated with significant reductions in insulin requirements. ${ }^{(18)}$ IGFBPs have emerged as a key regulator of insulin/IGF systems. Despite their structural homology, individual members of the IGFBP family may exert unique action. The function of IGFBP-1 on adipose tissue lipid metabolism and endocrine function may be linked with the development of obesity and insulin resistance.

In our study we found Type 2 diabetic group have IGF1 values statistically lower than non diabetic group $(\mathrm{P}=0.0001)$. Poulos et al. ${ }^{(19)}$ found low IGF-I levels in obese Type 2 diabetics. In contrast, Rajpatak et al. ${ }^{(13)}$ did not find an independent association between IGF-1 and diabetes among 922 subjects 65 years of age from the Cardiovascular Health Study. Srinivas and Anoop (20) found that, lower serum IGF-1 levels were positively associated with diabetes only in subjects $<65$ years of age and not in those $\geq 65$ years of age. Patients with type 2 diabetes often exhibit reduced circulating total IGF-I levels (21) One explanation is that chronic hyperinsulinemia induces GH receptor resistance. ${ }^{(22)}$ Under experimental conditions, hyperinsulinemia reduces not only GH receptor expression but also $\mathrm{GH}$ signaling both at receptor and postreceptor levels. ${ }^{(22)} \mathrm{We}$ found that, non diabetic group have IGFBP1 values statistically higher than Type2 diabetic group $(\mathrm{P}=0.041)$.Sandhu et al. ${ }^{(23)}$ found that, low IGFBP-I levels and an increased IGF-
I:IGFBP-1 ratio were strongly associated with increased levels of insulin and glucose in men and women.

In our study we found among Type 2 diabetic group, a significant negative correlation between levels of fasting blood glucose and those of IGF$1(\mathrm{r}=-0.517$ and $\mathrm{p}=.0001)$ and insignificant negative correlation between levels of fasting blood glucose and those of IGFBP1 ( $\mathrm{r}=-.278$ and $\mathrm{p}=.064)$.Golam Kabir stated that, ${ }^{(24)}$ IGF-1 was significantly $(\mathrm{r}=0.337, \mathrm{p}=0.025)$ associated with fasting serum glucose in simple Pearson's correlation which is also reflected in stepwise multiple regression where both free IGF-1 and IGFBP-1 showed themselves to be negatively associated with fasting serum glucose in IGT subjects.

In our study, we found insignificant negative correlation between IGF-1 and insulin ( $\mathrm{r}=0.175$ and $\mathrm{p}=0.250$ ) among Type 2 diabetic group, also we found insignificant negative correlation between IGFBP1 and insulin( $\mathrm{r}=-.155$ and $\mathrm{p}=.310)$ among Type2 diabetic group. M.G. Kabir et al. ${ }^{(25)}$ stated that, in stepwise multiple regression analysis, IGF-1 was inversely associated with fasting insulin and positively associated with insulin secretory capacity in type $2 \mathrm{DM}$ subjects Rajpathak et al. ${ }^{(26)}$ reported that, strong inverse correlation of IGFBP-1 with insulin among diabetic members of an elderly cohort.

In our study, we found a significant negative correlation between IGF-1 and insulin resistance (HOMA-IR) ( $\mathrm{r}=-.300$ and $\mathrm{p}=.045)$ among Type2 diabetic group. Also, we found a significant negative correlation between IGFBP1 and insulin resistance (HOMA-IR) among Type2 diabetic group $(r=-.315$ and $\mathrm{p}=.046)$ and insignificant negative correlation between IGFBP1 and insulin resistance(HOMA-IR) among non diabetic group $(\mathrm{r}=-.163$ and $\mathrm{p}=.441)$. Laboratory studies have shown that in the presence of insulin resistance, there is upregulation of insulin/IGF hybrid receptor expression in muscle. ${ }^{(27)}$ These receptors are largely responsive to IGF-I ${ }^{(27)}$, and additional data suggest that their binding could be as potent 
in stimulating peripheral glucose uptake as insulin binding with its receptor. ${ }^{(28)}$

Prior to the development of insulin resistance, however, the adverse metabolic effects of IGF-I may predominate. For example, IGF-I promotes preadipocyte differentiation and proliferation through activation of the insulin receptor substrate and mitogen-activated protein kinase pathways. (29) IGFBP-1 is a marker of declining beta cell function, just as has been observed for the incremental insulin response to glucose, ${ }^{(30)}$ this is consistent with the emergence of hepatic insulin resistance .Kuppan et al. ${ }^{(31)}$ stated that, Subjects with T2DM had significantly decreased levels of IGFBP-1 $(21.7 \pm 3.5 \mathrm{ng} / \mathrm{mL})$ compared with NGT subjects $(34.4 \pm 7.6 \mathrm{ng} / \mathrm{mL}, \mathrm{P}<.001)$. Liew et al. (32) have reported that, healthy glucose-tolerant Asian Indian subjects have an adverse combination of relative insulin resistance and low fasting IGFBP-1 levels.

In our study, we found insignificant negative correlation between IGF-1and duration of diabetes $(r=.013$ and $p=.952)$ and no correlation between IGFBP1 and duration of diabetes ( $\mathrm{r}=.098$ and $\mathrm{p}=.642$ ).IGFBP-1 is negatively related with insulin resistance, ${ }^{(14)}$ with the development of type 2 diabetes; (14) however, IGFBP-1 concentrations rise again despite persisting hyperinsulinemia, suggesting a complex interaction between pancreatic insulin output and hepatic insulin sensitivity. Clauson PG et al. stated that, ${ }^{(33)}$ levels of IGF-I decreased with diabetes duration and with increased blood glucose.

In our study, we found among Type 2 diabetic group insignificant negative correlation between IGF-1 and BMI(r=-.220 and $\mathrm{p}=.147)$ and insignificant negative correlation between IGFBP1 and BMI among non diabetic group(r=.161 and $\mathrm{p}=.497)$. Obesity may be associated with moderate elevation of free IGF-I levels, ${ }^{(34)}$ this can occur despite the relation of obesity with hyposecretion of growth hormone $(\mathrm{GH}),{ }^{(35)}$ the primary regulator of IGF-I production by the liver, ${ }^{(36)}$ because of IGF-I production by adipocytes, ${ }^{(37)}$ the stimulation of hepatic IGF-I synthesis by insulin. ${ }^{(38)}$ and insulin increases the fraction of circulating free IGF-I by down-regulating hepatic synthesis of IGFBP-1. ${ }^{(39)}$ Frystyck et al. ${ }^{(40)}$ have shown that the level of free IGF-1 increased in obese controls (BMI, $31.6 \pm 0.7$ ) compared to lean controls (BMI, 22.8 \pm 0.2 ), but in obese type 2 diabetes (BMI, 32.3 \pm 0.8 ) the level of free IGF-1 did not differ significantly from either lean or obese controls. M.G. Kabir et al. ${ }^{(25)}$ stated that, no significant difference of IGFBP-1 level was observed between the low (BMI 6 23) and high $(\mathrm{BMI}>23) \mathrm{BMI}$ group neither in type $2 \mathrm{DM}$ subjects nor in controls.

Interpretation of these findings is somewhat limited by the relatively small sample size of the study (number of diabetic cases $=25$, control cases=20) and the absence of data regarding additional IGFBPs, including IGFBP-2 and IGFBP-3.Prospective cohort studies of appropriate size, and with relevant data to control for other major risk factors, are needed to assess the fundamental question of whether the IGF-axis plays a significant etiopathogenic role in the development of type 2 diabetes.

\section{Conclusion}

From the results of the present study, we can conclude that our type 2 diabetes patients had IGF1 and IGFBP-1 values statistically lower than non diabetic group .There was a significant negative correlation between levels of FBG and those of IGF-1 among diabetic group. Diabetic group had significant negative correlation between IGF-1 and IR and also, diabetic group had significant negative correlation between IGFBP1 and IR. All of the above data emphasized that the IGFBP-1 protein deserved attention for our understanding of its relation and the insulin-like growth factor-1 to insulin resistance.

\section{Acknowledgement}

We would like to thank all our colleagues who helped us during the work in this study and to the participants without whom this study could not be performed. There are no financial or other relationships which could be construed as a 
conflict of interest and there are no sources of financial support for this study.

\section{References}

1. Daughaday WH, Rotwein P. Insulin-like growth factors I and II: peptide,messenger ribonucleic acid and gene structures, serum, and tissue concentrations. Endocr Rev 1989; 10:68-91.

2. R.S. Sherwin, K. Greenawalt, G.I. Shulman Simultaneous in-sulin-like growth factor I and insulin resistance in obese zucker rats. Diabetes, 1992;41: 691697.

3. S.Y. Nam, E.J. Lee, K.R. Kim .Effect of obesity on total and free insulin-like growth factor (IGF)-1, and their relationship to IGF-binding protein (BP)-1, IGFBP-2, IGFBP-3, insulin, and growth hormone .Int $\mathbf{J}$ Obes Relat Metab Disord, 1997;21:355-359.

4. Ritvos O, Ranta T, Jalkanen J, Suikkari A$\mathrm{M}$, et al. Insulin-like growth factor (IGF) binding protein from human deciduas inhibits the binding and biological action of IGF-I in cultured choriocarcinoma cells. Endocrinology 1988; 122:2150-7.

5. Holly JMP. The physiological role of IGFBP-1. Acta Endocrinol (Copenh) 1991;124: 55-62.

6. Westwood M, Gibson JM, Williams AC, et al. Hormonal regulation of circulating insulin-like growth factor binding protein1 phosphorylation status. J Clin Endocrinol Metab 1995; 85: 3520 -7.

7. Yki-Jarvinen, $H$. et al. Portal insulin concentrations rather than insulin sensitivity regulate serum sex hormonebinding globulin and insulin-like growth factor binding protein 1 in vivo. J. Clin. Endocrinol. Metab. 1995;80: 3227-3232.

8. K. Brismar, E. Fernqvist Forbes, J. Wahren, K. Hall Effect of insulin on the hepatic production of insulin-like growth factor-binding protein-1 (IGFBP-1), IGFBP-3, and IGF-I in insulin-dependent diabetes J Clin Endocrinol Metab,1994; 79: 872-878.

9. J. Frystyk, E. Vestbo, C. SkjÒrbÒk, C.E. Mogensen, H. Èrskov .Free insulin-like growth factors in human obesity .Metabolism, 1995;44 (Suppl 4) :37-44

10. Kaushal, K. et al.The impact of abnormalities in IGF and inflammatory systems on the metabolic syndrome. Diabetes Care2004; 27:2682-2688.

11. Travers, S.H. et al.Insulin-like growth factor binding protein-I levels are strongly associated with insulin sensitivity and obesity in early pubertal children. J. Clin. Endocrinol. Metab.1998; 83:1935-1939.

12. Maddux, B.A. et al.IGF-binding protein-1 levels are related to insulin-mediated glucose disposal and are a potential serum marker of insulin resistance. Diabetes Care 2006; 29: 1535-1537.

13. Rajpathak, S.N. et al. Insulin-like growth factor-(IGF)-axis, inflammation, and glucose intolerance among older adults. Growth Horm. IGF Res. 2008;18: 166173.

14. Heald, A.H. et al. Close relation of fasting insulin-like growth factor binding protein1 (IGFBP-1) with glucose tolerance and cardiovascular risk in two populations. Diabetologia 2001; 44:333-339.

15. Lewitt, M.S. et al.Insulin-like growth factor-binding protein-1 in the prediction and development of type 2 diabetes in middle-aged Swedish men. Diabetologia 2008; 51:1135-1145.

16. Møller N, Jørgensen JO. Effects of growth hormone on glucose, lipid, and protein metabolism in human subjects. Endocr Rev 2009;30:152-177.

17. RH IGF-I in NIDDM Study Group. Evidence from a dose ranging study that recombinant insulin-like growth factor-I effectively and safely improves glycaemic control in non-insulin dependent diabetes mellitus. Diabetes 1996; 45 (suppl): 27A. 
18. Crowne EC, Samra JS, Cheetham T et al. The role of IGF-binding proteins in mediating the effects of recombinant human IGF-I on insulin requirements in type 1 diabetes mellitus. J Clin Endocrinol Metab 2001; 86: 3686-91.

19. Poulos JE, Leggett Frazier N, Khazanie P et al. Circulating insulin-like growth factor I concentrations in clinically severe obese patients with and without NIDDM in response to weight loss. Horm Metab Res 1994; 26: 478-480.

20. Srinivas, Anoop et al. Association between Serum IGF-1 and diabetes among U.S. adults. Diabetes care 2010;33: 2257-2259.

21. Sandhu, M.S. et al. Circulating concentrations of insulin-like growth factor-I and development of glucose intolerance: a prospective observational study. Lancet 2002; 359: 1740-1745.

22. Xu J, Ji S, Venable DY, Franklin JL, Messina JL. Prolonged insulin treatment inhibits GH signaling via STAT3 and STAT1. J Endocrinol 2005;184:481-492.

23. Sandhu MS, Gibson JM, Heald AH et al.Association between insulin-like growth factor-I: insulin-like growth factor-binding protein-1 ratio and metabolic and anthropometric factors in men and women. Cancer Epidemiol Biomarkers Prev 2004; 13:166-170

24. Golam Kabir , Mosaraf Hossain et al .Association of serum free IGF-1 and IGFBP-1 with insulin sensitivity in impaired glucose tolerance (IGT) International Journal of Diabetes Mellitus 2010;2: 144-147.

25. Golam Kabir, MPhil Omar Faruque, Mohammad Alauddin et al. Association of serum free IGF-1 and IGFBP-1 with insulin sensitivity and insulin secretory defects in Bangladeshi type 2 diabetes mellitus. Journal of Taibah University Medical Sciences 2014; 9(2): 132-138

26. Swapnil N. et al .Insulin-Like Growth Factor Axis and Risk of Type 2 Diabetes in Women.DIABETES 2012; 61 ; 22482254.

27. Federici M, Porzio O, Zucaro L et al. Increased abundance of insulin/IGF-I hybrid receptors in adipose tissue from NIDDM patients. Mol Cell Endocrinol 1997;135:41-47.

28. Modan-Moses D, Janicot M, McLenithan JCet al. Expression and function of insulin/insulin-like growth factor I hybrid receptors during differentiation of 3T3-L1 preadipocytes. Biochem J 1998; 333:825831.

29. Kawai M, Rosen CJ. The IGF-I regulatory system and its impact on skeletal and energy homeostasis. J Cell Biochem 2010; 111:14-19.

30. Lyssenko V, Almgren P, Anevski D et al.Predictors of and longitudinal changes in insulin sensitivity and secretion preceding onset of type 2 diabetes. Diabetes2005; 54:166-174.

31. Kuppan Gokulakrishnan Kaliyaperumal et alCirculating levels of insulin-like growth factor binding protein-1 in relation to insulin resistance, type 2 diabetes mellitus, and metabolic syndrome (Chennai Urban Rural Epidemiology Study).Metabolism 2012; 61(1)43-46.

32. Liew CF, Wise SD, Yeo KP et al.Insulinlike growth factor binding protein-1 is independently affected by ethnicity, insulin sensitivity, and leptin in healthy, glucose-tolerant young men. J Clin Endocrinol Metab 2005; 90:1483-1488.

33. Clauson PG,Brismar K, Hall K Insulin-like growth factor-I and insulin-like growth factor binding protein-1 in a representative population of type 2 diabetic patients in Sweden. Scand J Clin Lab Invest. 1998 Jul; 58(4):353-60.

34. Rajpathak SN, Gunter MJ, Wylie-Rosett J, et al. The role of insulin-like growth factor-I and its binding proteins in glucose homeostasis and type 2 diabetes. Diabetes Metab Res Rev 2009; 25:3-12. 
35. Williams T, Berelowitz M, Joffe SN, et al. Impaired growth hormone responses to growth hormone-releasing factor in obesity. A pituitary defect reversed with weight reduction. N Engl J Med 1984;311:1403-1407.

36. Jones JI, Clemmons DR. Insulin-like growth factors and their binding proteins: biological actions. Endocr Rev 1995;16:334.

37. Wabitsch M, Heinze E, Debatin KM, Blum WF. IGF-I- and IGFBP-3-expression in cultured human preadipocytes and adipocytes. Horm Metab Res 2000;32: 555-559.

38. Böni-Schnetzler M, Schmid C, Mary JL, et al. Insulin regulates the expression of the insulin-like growth factor binding protein 2 mRNA in rat hepatocytes. Mol Endocrinol 1990;4:1320-1326.

39. Brismar K, Fernqvist-Forbes E, Wahren J, Hall K. Effect of insulin on the hepatic production of insulin-like growth factorbinding protein-1 (IGFBP-1), IGFBP-3, and IGF-I in insulin-dependent diabetes. J Clin Endocrinol Metab 1994; 79: 872-878.

40. FrystykJ, SkjaerbaekC, VestboE, et al. Circulating levels of free insulin-like growth factors in obese subjects: the impact of type 2 diabetes. Diabetes Metab Res Rev 1999; 15: 314-322. 